Original Research Paper

\title{
Peningkatan Kapasitas Petani Melalui Pelatihan Pembukuan Usahatani di Desa Otak Rarangan Kecamatan Wanasaba Kabupaten Lombok Timur
}

\author{
Dudi Septiadi $^{1 *}$, Rosmilawati ${ }^{1}$, Abdullah Usman ${ }^{1}$, I Gusti Lanang Parta Tanaya ${ }^{1}$, Asri Hidayati ${ }^{1}$ \\ ${ }^{1}$ Program Studi Agribisnis, Universitas Mataram, Mataram, Indonesia;
}

https://doi.org/10.29303/jpmpi.v3i2.945

Sitasi: Septiadi, D., Rosmilawati., Usman, A., Tanaya, I. G. L. P \& Hidayati, A. (2021). Peningkatan Kapasitas Petani Melalui Pelatihan Pembukuan Usahatani di Desa Otak Rarangan Kecamatan Wanasaba Kabupaten Lombok Timur. Lombok Tengah. Jurnal Pengabdian Magister Pendidikan IPA, 4(3)

\section{Article history}

Received: 31 Juli 2021

Revised: 6 September 2021

Accepted: 7 September 2021

*Corresponding Author: Dudi Septiadi, Program Studi Agribisnis, Universitas

Mataram, Mataram, Indonesia; Email: dudi@unram.ac.id

\begin{abstract}
Abstrak: Penggunaan pembukuan dalam usahatani merupakan jenis teknologi yang efektif dalam mengontrol kebijakan pengelolaan usahatani. Petani sebagai pengelola usahatani dapat mengetahui kelemahan dalam penyusunan perencanaan dan penyelenggaraan usahatani. Tujuan kegiatan pengabdian ini adalah untuk; 1) memberikan pemahaman kepada petani terkait pentingnya pembukuan usahatani; 2) melatih petani untuk membuat catatan pembukuan usahatani. Pengabdian dilaksanakan di Desa Otak Rarangan, Kecamatan Wanasaba, Kabupaten Lombok Timur. Kegiatan ini dilaksanakan dengan sasaran para petani dari perwakilan kelompok tani sebanyak 20 orang. Metode pelaksanaan kegiatan dengan metode Forum Group Discussion (FGD) dan Workshop. Hasil kegiatan pengabdian ini mampu memberikan pemahaman baru bagi petani terkait pentingnya pencatatan dan pembukuan usahatani. Petani bisa membedakan antara sumber penerimaan dan sumber pengeluaran kegiatan usahatani. Berdasarkan hasil simulasi pada workshop pencatatan dan pembukuan usahatani, petani mengetahui kondisi keuangan usahataninya selama satu musim tanam sebelumnya. Petani bisa menggunakan buku catatan usahatani yang telah dibuat untuk kegiatan musim tanam berikutnya secara berkelanjutan.
\end{abstract}

Kata Kunci: pembukuan; pengabdian; peningkatan kapasitas; petani.

\section{Pendahuluan}

Petani dalam usahataninya tidak hanya berkepentingan dalam peningkatan produksinya, tetapi dapat meningkatkan pendapatan dan keuntungan bagi petani (Mubyarto, 1989). Peningkatan keuntungan diharapkan berdampak pada peningkatan kehidupan ekonomi keluarga menjadi lebih baik. Dalam mencapai tujuan tersebut, petani selalu memperhitungkan untung ruginya walaupun tidak secara tertulis (Athaillah,
2020). Petani dalam melakukan usahataninya, disamping berperan sebagai pemilik dan tenaga kerja utama, juga sebagai pengelola (manajer). Menurut Ratnasari et al, (2017) aspek manajemen adalah kunci kesuksesan usahatani. Tantangan dalam aspek manajemen adalah bagaimana kemampuan manajerial petani dalam mengelola sumberdaya yang dimiliki (Fadhla, 2017). Diantara sumberdaya tersebut adalah sumberdaya lahan, modal dan tenaga kerja.

Tujuan utama petani dalam melakukan usahatani adalah bagaimana petani mandapatkan keuntungan dari usahatani dan meningkatkan 
kesejahteraan keluarga. Untuk mengetahui apakah usaha yang dijalankan oleh petani mengalami keuntungan atau tidak, diperlukan adanya pembukuan usahatani. Sehingga diperlukan pemahaman pembukuan usahatani dalam mengembangkan usahatani (Putri et al, 2020). Pembukuan dalam suatu usaha bisnis adalah dasar dari sistem akuntansi. Undang-Undang Nomor 28 tahun 2007 Pasal 28 mengatakan Pembukuan adalah suatu proses pencatatan yang dilakukan secara teratur untuk mengumpulkan data dan informasi keuangan yang meliputi harta, kewajiban, modal, penghasilan dan biaya serta harga perolehan dan penyerahan barang atau jasa, yang ditutup dengan menyusun laporan keuangan berupa neraca dan laporan laba rugi untuk periode tahan tersebut.

Semua bisnis membutuhkan sebuah pembukuan dalam menjalankan bisnis, termasuk juga bisnis usahatani (Tohir, 1983). Ada beberapa manfaat penting dari aktivitas pembukuan keuangan bagi suatu bisnis yaitu: 1) Mengetahui besarnya keuntungan atau kerugian usahatani; 2) Mengetahui transaksi apa saja yang telah dilakukan oleh petani; 3) Untuk menilai tingkat kemajuan usahatani. Seringkali disebutkan bahwa penggunaan pencatatan usahatani mampu mengontrol pengelolaan kegiatan usahatani. Melalui pembukuan usahatani, petani mampu mengidentifikasi kelemahan dari seluruh kegiatan usahatani, mulai dari perencanaan dan pelaksanaan usahatani sampai kegiatan panen dan pasca panen. Perbaikan manajemen usahatani melalui penerapan kegiatan pembukuan diharapkan memperbaiki aspek perencanaan dan dapat meningkatkan produktisi usahatani pada musim tanam berikutnya. Hal ini didukung oleh penelitian yang dilakukan Mariyono dan Rachmansyah (2010), hasil penelitiannya menyatakan bahwa pelatihan mampu menaikkan tingkat produksi dan menurunkan biaya produksi. Dengan demikian, mengajarkan cara-cara pembukuan usahatani kepada para petani adalah sangat penting.

Berdasarkan data-data pada pembukuan usahatani, selanjutnya dapat dilakukan analisis usahatani yang berfungsi sebagai sumber informasi bagi manajemen perencanaan, pelaksanaan, pengawasan dan pengambil keputusan. Analisis usahatani juga digunakan untuk mengidentifikasi kegiatan usahatani, apakah suatu usahatani memperoleh keuntungan yang menjanjikan atau sebaliknya. Serta mampu menilai tingkat kelayakan usahatani untuk dijalankan. Bagi petani, pembukuan dan analisis usahatani dapat dijadikan dasar untuk melakukan permohonan pinjaman modal usahatani kepada pihak-pihak penyedia modal usahatani seperti: Bank, BUMN dan lembaga lainnya.

Desa Otak Rarangan merupakan salah satu Desa di Kecamatan Wanasaba Kabupaten Lombok Timur, dimana mata pencaharian penduduknya sebagian besar bekerja disektor pertanian. Petani di Desa Otak Rarangan masih belum menerapkan aspek manajemen keuangan dengan baik. Salah satu diantaranya adalah pembukuan usahatani. Para petani belum menyadari arti pentingnya dari pembukuan dan analisis usahatani. Keadaan ini disebabkan karena perilaku, sikap, pengetahuan dan keterampilan petani tentang pembukuan dan analisis usahatani khususnya di Desa Otak Rarangan, masih rendah. Materi penyuluhan pada kelompok-kelompok tani dari penyuluh, belum menyentuh sampai pembukuan dan analisis usahatani, sehingga pengabdian pada masyarakat berupa pelatihan pembukuan usahatani, khususnya di Desa Otak Rarangan Kecamatan Wanasaba Kabupaten Lombok Timur ini sangat perlu dilakukan. Kepentingan ini menjadi bertambah, dengan melihat bahwa pemerintah juga membutuhkan data-data usahatani sebagai masukan dalam menetapkan kebijakan di bidang pertanian. Dengan keterbatasan petani di Desa Otak Rarangan, khususnya keterbatasan dalam penggunaan komputer, menyebabkan mereka tidak dapat menggunakan aplikasi pembukuan usahatani yang tersedia, sehingga mereka perlu dilatih untuk dapat melaksanakan pembukuan dan analisis usaha secara manual dengan metode yang sederhana, sesuai kemampuan mereka.

\section{Metode}

Metode pelaksanaan kegiatan pengabdian pada masyarakat ini dilakukan dengan metode Forum Group Discussion (FGD) dipadupadankan dengan Workshop pembukuan usahatani. Kegiatan FGD dilakukan dengan memberikan materi klasikal terkait peran strategis sektor pertanian dan urgensi melakukan pencatatan dalam kegiatan usahatani, dilanjutkan dengan diskusi. Setelah kegiatan FGD dilakukan, kegiatan selanjutnya adalah kegiatan workshop pembukuan usahatani dengan peserta dibimbing oleh Tim Pelaksana Pengabdian Pada 
Masyarakat dibantu dengan Mahasiswa dan Perangkat Pemerintah Desa setempat.

Kegiatan dilakukan dengan mengundang masyarakat (mitra) yang diwakili oleh masingmasing perwakilan kelompok tani sebagai sasaran kegiatan pengabdian. Petani yang terlibat dalam kegiatan ini sebanyak 20 orang petani yang mewakili petani di Desa Otak Rarangan, Kecamatan Wanasaba, Kabupaten Lombok Timur. Petani yang dipilih sebagai sasaran kegiatan mewakili Kelompok Tani yang ada di Desa Otak Rarangan. Sasaran kegiatan yang dipilh sudah terlebih dahulu dikoordinasikan antara Tim Pelaksana Pengabdian dengan Pemerintah Desa.

Target kegiatan Pengabdian Pada Masyarakat ini diharapkan petani memahami pentingnya melakukan pencatatan pembukuan usahatani dan mengimplementasikan pembukuan usahatani secara berkelanjutan.

\section{Hasil dan Pembahasan}

\section{Profil Desa Otak Rarangan}

Secara Geografis dan secara administratif Desa Otak Rarangan menurut BPS (2014) yang bersumber dari hasil Pendataan Potensi Desa/Kelurahan tahun 2014. Lokasi Desa Otak Rarangan terletak pada titik koordinat Garis Lintang: 0806657 LU/LS, Garis Bujur: 11603926 BT, dan Ketinggian dari permukaan air laut (dpal): 355 meter.

Batas wilayah Desa Otak Rarangan

1. Sebelah Utara : Desa Bebidas

2. Sebelah Selatan : Wanasaba Lauk

3. Sebelah Barat : Karang Baru Timur

4. Sebelah Timur : Desa Suela

Pembagian Wilayah

Desa Otak Rarangan terdiri dari 3 Wilayah Kekadusan dan 33 Rukun Tetangga (RT). Pembagian wilayah dapat dirinci sebagai berikut.
1. Kadus Otak Rarangan
: $10 \mathrm{RT}$
2. Kadus Otak Rarangan Lauk
: 12 RT
3. Kadus Jor bat
$: 11 \mathrm{RT}$

\section{Kegiatan Pelatihan Pembukuan Usahatani}

Kegiatan pelatihan dilaksanakan pada hari Rabu, 11 Agustus 2021 berlokasi di balai desa Otak Rarangan. Persiapan di lapangan dilakukan dengan dibantu mahasiswa Program Studi Agribisnis Universitas Mataram yang bertempat tinggal dekat dengan lokasi pengabdian. Acara Pengabdian Pada Masyarakat ini dihadiri oleh 20 orang dari perwakilan Kelompok Tani yang ada. Petani yang terlibat adalah kegiatan pengabdian sebagian besar membudidayakan tanaman padi dan hortikultura. Petani setempat juga memadukan kegiatan usahatani dengan memelihara hewan ternak seperti sapi dan kambing. Acara juga dihadiri oleh seorang Babinsa, yang berpatroli untuk meyakinkan acara berjalan dengan mengindahkan protokol kesehatan yang ketat. Penerapan protokol kesehatan ditunjukkan pada Gambar 1 dan Gambar 2 yang menunjukkan kegiatan pemberian masker pada peserta kegiatan pengabdian dan handsanitizer yang disediakan oleh panitia kegiatan pengabdian. Pada kegiatan pengabdian ini Kepala Desa berhalangan hadir, dan diwakili oleh kadus setempat.

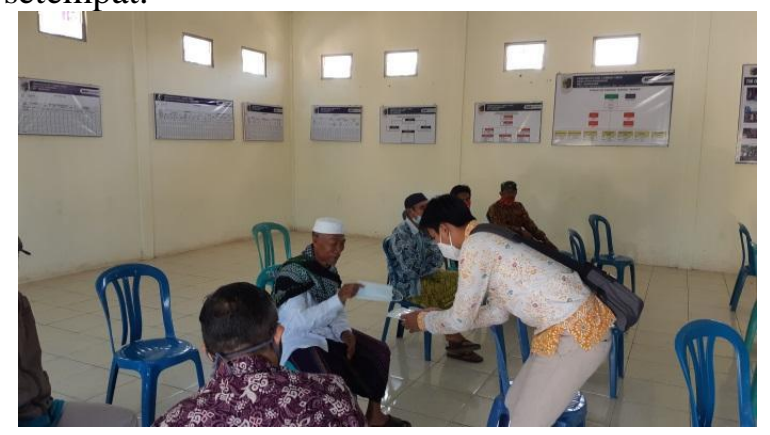

Gambar 1. Pembagian masker pada peserta kegiatan

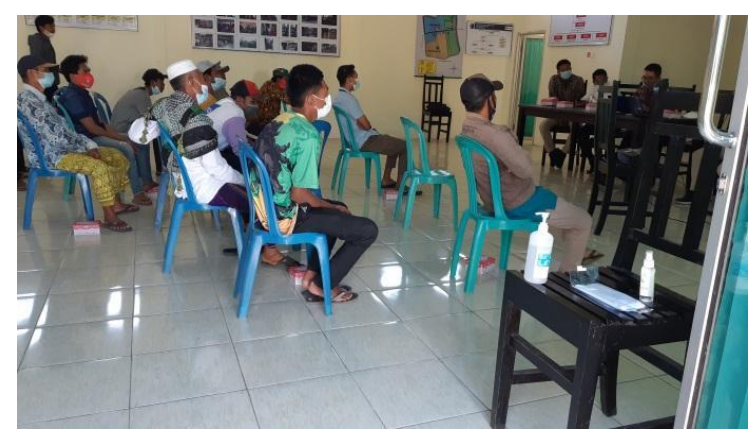

Gambar 2. Pelaksanaan dengan protokol kesehatan

Kegiatan diawali dengan sambutan dari ketua tim pengabdian masyarakat, ketua program studi agribisnis, dan pihak pemerintah desa setempat sekaligus membuka acara kegiatan pengabdian secara resmi. Kegiatan dilanjutkan dengan penyampaian materi untuk memotivasi petani dan memberikan pemahaman tentang manfaat dan cara-cara melakukan pembukuan dan analisis usahatani secara manual. Kegiatan tersebut ditunjukkan pada Gambar 3. Selanjutnya dilakukan kegiatan diskusi terkait materi yang sudah 
disampaikan. Terdapat beberapa temuan penting ketika diskusi dengan petani, dimana nyaris semua petani tidak pernah melakukan pencatatan pembukuan usahatani yang mereka tekuni selama bertahun-tahun.

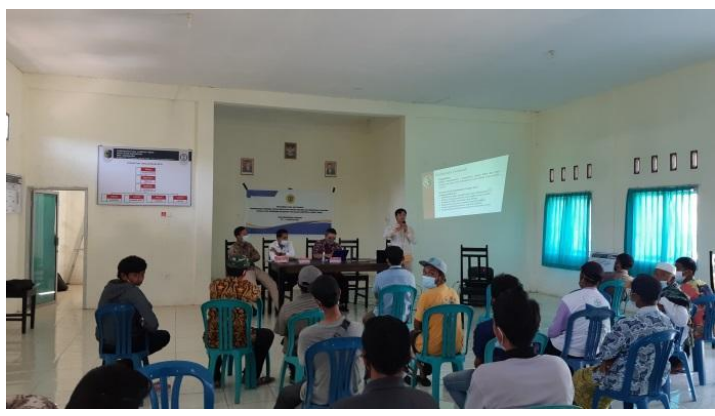

Gambar 3. Penyampaian materi penyuluhan

Kegiatan pengabdian ini diharapkan sebagai pemicu bagi petani untuk mau mencatat kegiatan usahataninya dengan baik. Beberapa manfaat dari mencatat kegiatan usahatani diantaranya adalah;

1. Dapat dijadikan petunjuk tentang tingkat perkembangan usahatani. Perkembangan tersebut diantaranya adalah perkembangan harga, kebutuhan dan harga saprodi, informasi pendapatan, dan kebutuhan modal.

2. Bagi pemerintah, peneliti \& penyuluh pertanian, buku catatan usahatani merupakan sumber informasi statistik yang berguna.

3. Alat untuk menilai keberhasilan usaha yaitu sebagai bukti layak tidaknya usaha.

4. Bagi petani catatan pembukuan dapat dijadikan informasi perbankan apabila petani melakukan pinjaman modal ke Bank.

5. Petani mampu mengamankan dan mengawasi asetnya, sehingga mampu mencegah penyimpangan dan pemborosan.

6. Petani mampu mengidentifikasi strength dan weakness dari usahataninya, sehingga petani bisa merencanakan dengan baik kegiatan usahatani pada musim tanam berikutnya.

7. Dasar penyusunan kebijakan Pemerintah Pusat dan Daerah.

Pada sesi FGD, selain mengungkapkan lemahnya pencatatan usahatani. Petani juga mengungkapkan beberapa kendala usahatani. Diantaranya adalah sulitnya petani dalam mengakses pupuk bersubsidi di Desa Otak Rarangan. Petani mengungkapkan seringkali pupuk bersubsidi mengalami kelangkaan. Ketika pupuk bersubsidi tersedia, jumlahnya terbatas dan ada persyaratan administratif yang harus dilengkapi. Solusi yang ditawarkan untuk mengatasi hal tersebut adalah dengan memanfaatkan potensi yang ada di lingkungan petani sendiri. Di Desa Otak Rarangan, selain petani menjalankan usahatani, petani juga memelihara hewan ternak. Sebagian besar hewan ternak yang diusahakan adalah peternakan sapi. Potensi ini bisa dimanfaatkan dengan mengolah kotoran sapi menjadi pupuk organik (Nugraha, 2013). Artinya limbah kotoran sapi yang selama ini mengotori lingkungan bisa digunakan untuk mengatasi kelangkaan pupuk yang dikeluhkan petani sebelumnya (Huda \& Wikanta, 2016). Temuan ini penting sebagai dasar pemikiran kegiatan pengabdian berikutnya. Selain itu, petani juga mengeluhkan ketika musim panen tiba, harga komoditas pertanian mengalami penurunan secara drastis. Hal ini dikarenakan rantai pasok yang panjang dari petani sampai ke konsumen akhir. Sebagian besar petani menjual hasil panen ke tengkulak dengan harga yang murah. Selama ini tengkulak dan pedagang pengepul yang memperoleh keuntungan besar. Solusi yang ditawarkan untuk masalah ini adalah petani melakukan koordinasi dengan kelompok tani dan BUMDes untuk mendirikan kelembagaan. Kelembagaan ini bisa berbentuk koperasi pertanian. Koperasi pertanian beranggotakan seluruh kelompok tani yang ada (Nuryanti \& Swastika, 2011). Modal awal koperasi bersumber dari anggota dengan dibantu BUMDes dalam pengelolaan keuangan. Koperasi nantinya ditugaskan untuk menyerap hasil panen petani dengan harga yang sesuai (Pujiyono \& Nugraha, 2016). Artinya petani mendapatkan kepastian harga. Hasil panen yang sudah diserap koperasi lalu dijual langsung ke konsumen tingkat akhir. Artinya koperasi ini memotong panjangnya rantai pasok dan menggantikan peran tengkulak, pengepul dan pedagang besar.

Selanjutnya, pada sesi kedua dilakukan workshop cara melakukan pembukuan usahatani dan analisis usahatani secara sederhana, dengan cara masing-masing peserta mempraktekkan langsung pembukuan usahatani. Jumlah peserta adalah 20 orang yang terdiri dari perwakilan kelompok tani yang ada di desa Otak Rarangan. Setiap peserta berperan aktif dalam pelatihan ini, dan mereka dibimbing untuk dapat melakukan pencatatan pada buku yang sudah disiapkan oleh Tim Pelaksana Pengabdian. 


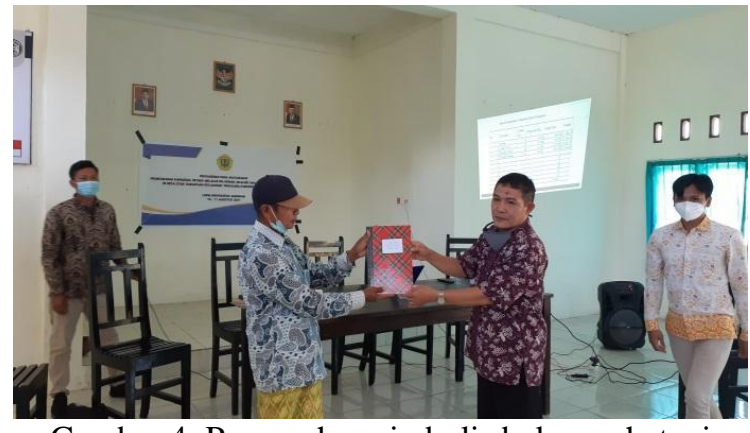

Gambar 4. Penyerahan simbolis buku usahatani

Di akhir kegiatan, setiap peserta sudah memiliki buku catatan usahataninya masing-masing yang sudah terisi dengan data usahatani mereka masing-masing berdasarkan pelaksanaan usahatani musim tanam yang lalu. Dan buku tersebut akan menjadi pendorong mereka untuk tetap melakukan pencatatan usahatani mereka di musim-musim tanam selanjutnya. Pada Gambar 4, menunjukkan kegiatan penyerahan secara simbolis buku usahatani yang siap digunakan petani dari tim pelaksana pengabdian. Dalam pelatihan ini, melibatkan 1 orang mahasiswa semester akhir yang berperan dalam mendampingi dan membimbing petani dalam melakukan pencatatannya. Gambar 5 menunjukkan kegiatan foto bersama Tim pelaksana kegiatan pengabdian pada masyarakat.

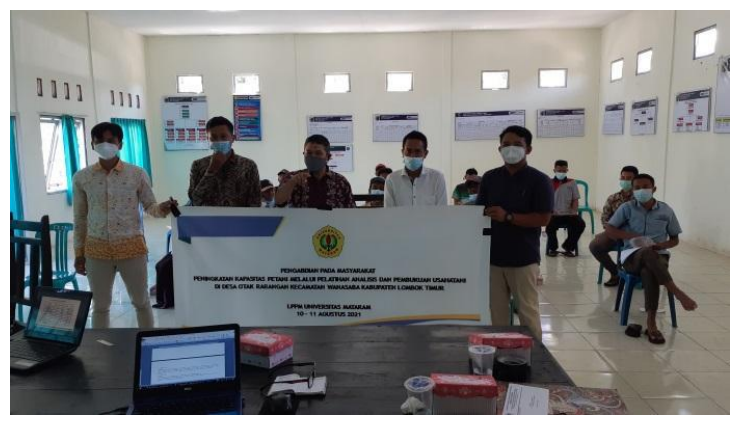

Gambar 5. Tim pelaksana pengabdian

\section{Kesimpulan}

Kegiatan pengabdian telah disampaikan dengan metode FGD dan Workshop dan berjalan dengan baik. Peserta mengikuti dengan baik kegiatan dan direspon positif oleh peserta. Kegiatan ini telah memberikan pemahaman baru bagi petani terkait pentingnya pencatatan dan pembukuan usahatani. Petani bisa membedakan antara sumber penerimaan dan sumber pengeluaran kegiatan usahatani. Berdasarkan hasil simulasi pada workshop pencatatan dan pembukuan usahatani, petani mengetahui kondisi keuangan usahataninya selama satu musim tanam sebelumnya. Petani bisa menggunakan buku catatan usahatani yang telah dibuat untuk kegiatan musim tanam berikutnya secara berkelanjutan

\section{Saran}

Saran untuk kegiatan pengabdian pada masyarakat berikutnya untuk memberikan penyuluhan terkait pengolahan limbah kotoran sampi menjadi pupuk organik. Hal ini didasarkan pada temuan adanya limbah kotoran sapi yang belum dikelola dengan baik dan menimbulkan pencemaran lingkungan.

\section{Ucapan Terima Kasih}

Penulis mengucapkan terima kasih kepada Rektor Universitas Mataram, Ketua LPPM dan Dekan Fakultas Pertanian Unram atas pendanaan kegiatan Pengabdian Pada Masyarakat melalui dana PNBP Universitas Mataram tahun 2021.

\section{Daftar Pustaka}

Athaillah, T. 2020. Pembukuan Usaha Tani Padi di Desa Leuhan Kecamatan Johan Pahlawan Kabupaten Aceh Barat. Jurnal Abdimas Bina Bangsa, 1(1), 80-86.

BPS 2014. Hasil Pendataan Potensi Desa/ Kelurahan. BPS Lombok Timur

Fadhla, T. 2017. Analisis Manajemen Usaha Tani dalam Meningkatkan Pendapatan dan Produksi Padi Sawah di Kecamatan Tangan-Tangan Kab. Aceh Barat Daya. Jurnal Visioner \& Strategis, 6(2).

Huda, S., \& Wikanta, W. 2016. Pemanfaatan Limbah Kotoran Sapi Menjadi Pupuk Organik Sebagai Upaya Mendukung Usaha Peternakan Sapi Potong di Kelompok Tani Ternak Mandiri Jaya Desa Moropelang Kecamatan Babat Kabupaten Lamongan. AKSIOLOGIYA: Jurnal Pengabdian Kepada Masyarakat, 1(1), 26-35.

Mariyono, J. dan Rachmansyah, Y. 2010. Dampak Sekolah Lapangan Pengendalian Hama Terpadu Pada Produksi Kedelai Di Jawa Timur: Analisis Ekonomi. Dinamika 
Sosial Ekonomi, 6 (2): 129-144.

Mubyarto, 1989. Pengantar EKonomi Pertanian Edisi III. LP3ES. Jakarta

Nugraha, S. P. 2013. Pemanfaatan Kotoran Sapi Menjadi Pupuk Organik. Asian Journal of Innovation and Entrepreneurship, 2(03), 193-197.

Nuryanti, S., \& Swastika, D. K. S. 2011. Peran kelompok tani dalam penerapan teknologi pertanian. In Forum penelitian agro ekonomi (Vol. 29, No. 2, pp. 115-128).

Pujiyono, A., \& Nugraha, H. S. 2016. Strategi Pembentukan Koperasi Pertanian Syariah di Jawa Tengah: Pendekatan Analytical Network Process (Anp). In Seminar Nasional Multi Disiplin Ilmu Unisbank 2016. Stikubank University.

Putri M. G., Sirma, I. N., \& Bernadina, L. 2020. Manajemen Usaha tani Terung Ungu Di Kelu rahanTuatuka Kecamatan Kupang Timur Kabupaten Kupang. Jurnal EXCELLENTIA Volume IX No 1 hal 5057.

Ratnasari, D., Rauf, A., \& Boekoesoe, Y. 2017. Analisis Hubungan Manajemen Usaha tani Padi Sawah Dengan Tingkat Keberhasilan Gapoktan Serumpun (Studi Kasus Gapoktan Serumpun Kota Gorontalo). AGRINESIA. Vol 2 no.1, November 2017.

Tohir, K. 1983. Seuntai Pengetahuan Tentang Usaha Tani Indonesia. Bina Aksara.

Jakarta. 